(C) 1989 ISIJ

IIIIIIIIIIIIIIIII

論 文

|/IIIIIIIIIIIIIII!
電磁気力による溶融金属の微粒化

佐々健介* ${ }^{*}$ 安形直人*2 . 小塚敏之 ${ }^{* 3} \cdot$ 浅井滋生 $* 4$

\title{
Atomization of Molten Metal by Use of Electromagnetic Force
}

\author{
Kensuke Sassa, Naohito Agata, Toshiyuki Kozuka and Shigeo Asai
}

\begin{abstract}
Synopsis :
A new atomization process is proposed in which molten metal is atomized by electromagnetic energy instead of kinetic one produced by fluid impingement or disk rotation in the conventional atomization processes. This electromagnetic atomization process was tested to clarify characteristics of atomizing molten metal. It was found that a crucial operation factor is a contacting condition of molten metal with an electrode. In order to control the condition, a delay time controller unit was developed and incorporated in the electromagnetic atomization process. It is noticed that this controller works well to produce the better uniform size particles than those of conventional atomization processes.

A linear relation between the impulse which is defined as the product of the imposed electromagnetic force and the period of current passing, and the momentum which is defined as the product of the mass and the velocity of splashed particle, is found by use of experimental data and this fact is explained from a theoretical view point.

Key words: powder metallurgy; electromagnetic metallurgy; atomization; electromagnetic atomization ; electromagnetic processing of materials; spray casting ; flame coating.
\end{abstract}

\section{1. 緒 言}

現在，金属粉末は機械的，化学的，あるいは物理化学 的方法によって造られているが，中でも，溶融金属から 直接，金属粉末を得る各種噴霧法が主流をなしている. 溶融金属の噴霧化においては，流体あるいは固体の連動 エネルギーを利用してメタルと流体 (ガス, 液体) 間, メタルと固体（ディスク）間の衝突を介した飛散が図ら れている，そのため，噴霧化には常に偶発的で不確定な 因子が絡むことは避けられず，得られる金属粉末の粒度 分布には必然的に広がりが生じがちである。また，制御 可能な操作变数も少なく，そのため粒度分布の広がりと 平均粒子径を的確に制御することは困難であると考えら れる。そのほか，上記噴霧法に打いては雲囲気が限定さ れるものもあり，その適用が困難な場合も生ずる。

一方, 近年, 直接成型プロセスとして，スプレー・キャ スティングや半凝固した粒滴を双ロール法を用いて压延 する方法 ${ }^{1)}$ が試行されている。 そこでは，機械的回転部 を有しない小型の粒滴化装置の開発が望まれている。
以上の観点を踏まえて，本研究では，連動エネルギー に代わり電磁エネルギーを利用する溶融金属の微粒化法 を考案し，その試行実験を行う。そして，粒滴化状況の 観察結果に基づいて，考案したプロセスによる微粒化の 叮否と主要操作因子を明らかにする。

\section{2. 従来の方法と電磁微粒化法の原理}

\section{$2 \cdot 1$ 従来の方法}

現在工業的に用いられている紼粒化法は，グレィニン グ (Graining)，ショティング (Shotting), 噴霧法 (Atomization) の 3 種類に分類される2).なかでも，噴 霧法は溶解可能な金属を効率的に細粒化するものであ り，大きく次の三つの方法に分類できる3).

(1)水噴霧法あるいはガス噴霧法

(2)遠心噴霧法

(3)真空噴霧法

(1)水噴霧法は溶融金属に高压ジェット水を吹き付け， 流体の運動エネルギーにより噴霧させる力法である，本 法で製造される粉末の平均粒度は，現状の生産規模設備

昭和 63 年 3 月本会講演大会にて発表 昭和 63 年 8 月 25 日受付 (Received Aug. 25, 1988)

* 名古屋大学工学部 (Faculty of Engineering, Nagoya University, Furo-cho Chikusa-ku Nagoya 464)

*2 名古屋大学工学部 (現: 日本電装(株)) (Faculty of Engineering, Nagoya University, Now Nippondenso Co., Ltd.)

*3 名古屋大学工学部 (現: 熊本大学) 工博 (Faculty of Engineering, Nagoya University, Now Kumamoto University)

*4 名古屋大学丁学部 T. 博 (Faculty of Engineering, Nagoya University) 
ではほぼ 50 70 $\mu \mathrm{m}$ であり，粉末の形状は不規則なも のになりがちである。一方，ガス噴霧法は高压の窒素ガ ス，アルゴンガスあるいは空気を溶融金属流に吹き付け るものである.この方法で得られる粉末の平均粒径は水 噴霧法のものと，ほぼ闹等であるが，形状は球形になり やすい.

（2遠心噴霧法には高速度で回転する円板状に溶湯を流 下させ，遠心力に上り噴霧化を四るもの市 とその改良法 であるプラズマ(山転電極法昼がある，後者は，高速回転 する消耗電極をプラズマによって溶解し，遠心力によっ て噴霧化するものである。この方法では溶融金属がるつ ぼやノズルと接触しないため, その污染を避けることが できる。このす法で製造される粉末の平均粒径は 150 $200 \mu \mathrm{m}$ 程度で, 形状は球状のものが多い.

(3)真空噴霧法としては，水素ガスを吸蔵させた溶融金 属を真空中へ噴出させ，吸蔵された水素が真空中へ放出 される際の運動エネルギーにより噴霧化する方法があ $る^{6)}$. この場合，粉末の平均粒径は約 $40 \sim 60 \mu \mathrm{m}$ となっ ている.

以上, (1) と (2)の各種噴霧法は, 溶湯と噴霧媒体 (ガス, 液体、周体) の衝突時に生ずる運動エネルギーの飛散を 利用するものである。また（3)においても内部エネルギー として蓄積されたガスの放出に伴う運動エネルギーに よっている. そのため上述した各種噴霧法とも, 噴霧化 に当たっては偶発的で不確定な因子が生ずることは避け られない，その結果，製造された粒子はおのずと広い粒 度分布を持ち、粒度分布と粒形を的確に制御することは 困難である。また，(1)および(3にに扔いては，噴霧化媒体 として気体や液体が用いられるため化学的な不適合が生 じ，場命によっては適用できる金属種も限定されること になる. (2)においては, 回転円板に熱灾力に伴う歪みが 生じると，それに大きな遠心力が作用して回転円板の破 損に慗るため回転速度は制約されることになる.プラズ

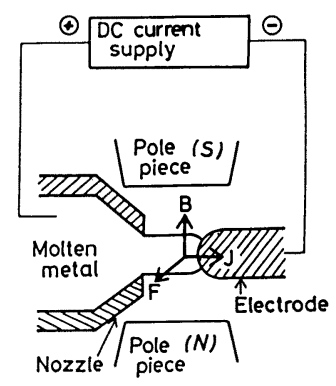

Fig. 1. Schematic view of electromagnetic atomization.
マ回転法においては，粒径をより小さくするためには消 耗電極の回転数を上げる必要があるが, 電極の軸対称性 を保つことが難しいことから回転数の増大は困難となっ ている.このように, 従来法の種々の問題点は噴霧化に 運動エネルギーを使用する点に起因するものが多く，以 上述べた問題点の解決策が模索されている.

\section{$2 \cdot 2$ 電磁微粒化法の原理}

本報で提案する電磁微粒化法は, 上述した従来法の問 題点を克服するため噴霧化に作用する運動エネルギーに 代わり電磁エネルギーを利用する溶融金属の粒滴化法で あり，その基本原理はフレミングの左手の法則である.

Fig. 1 に本プロセスの基本原理を示す.ノズルから水 平方向に流出する溶融金属がノズルと対向して設けられ た電極に接触した際に, 電気的な閉回路が形成されて溶 融金属中に直流電流が流れるように装置を構成する。， ズルから流出する溶融金属中を流れる電流 $(J)$ の方向 と直交する磁場 $(B)$ をノズルと電極間に印加しておく. 溶融金属が電極に接触すると電流が流れ，フレミングの 左手の法則によって, 溶融金属内に電磁体積力 $(F)$ が 紙面に垂直方向に誘発され，ノズルと電極間に位置する 溶融金属が飛散される。飛散の結果, 電流は遮断される が, 引き続いて流出する溶融金属が電極に接触して再び 通電され，電磁体積力により溶融金属が飛散される，飛 散に伴う電流の遮断, 通電の繰返しによって, 連続的に 溶融金属の粒滴化がなされることになる.

溶融金属に働く界面張力による保持力が張力に勝り， ノズルー電極間に溶融金属がいったん保持され，それが 電磁気力によって飛散されるためには次の条件が満足さ れねばならない。

$V J B>\pi d \gamma \geqq m g$

ここで, $\pi d \gamma$ はノズル-電極間の溶融金属を円柱形状に 近似した場合に溶融金属に働く表面張力である.

\section{3. 実験装置および方法}

本研究で用いた実験装置の模式図を Fig. 2 に示す. 実験装置は(1)定電流·定電圧直流電源, (2)溶融金属供給 系, (3)電極, (4)永久磁石, (5)電流・電圧記録計と後で詳 細を述べる(6)遅延時間設定装置から構成されている.

パイレックスガラス製の容器内にスズ $300 \mathrm{~g}$ を装入 し, 加熱溶解する. (7)湯溜部および8)ノズル先端部に設 定した(9)熱電対（K）により温度を測定し，所定の温度 に保持した，湯溜部に黒鉛製の正極を浸漬し，負極をノ ズルに相対向する位置に設定したささらに，電源の電流 と電圧を調整した後, $\mathrm{N}_{2}$ ガスにより湯溜部から溶融金 属を流出させた。この溶融金属の流出速度はガス流量を 


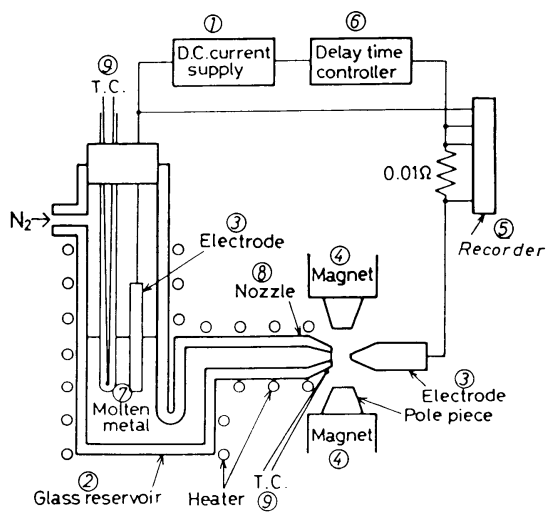

Fig. 2. Schematic view of experimental apparatus.

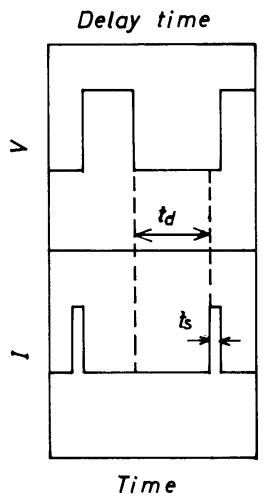

Fig. 3. Schematic patterns of voltage and current indicating the funtion of the delay time controller.

調整することにより制御した。一方，ノズルと電極間の ギャップ位置が永久磁石の磁極間の最大磁束密度の部分 となるよう磁石を設定したが，その際，鉛直上向きの磁 場を印加するように下側にN極，上側にS 極を配した。

ノズルと電極間距離はマニピュレーターによって 0.01 $\mathrm{mm}$ の精度で調整した，予備実験の結果，電極と溶融金 属の接触状態が常に同一とはならず，微視的に見ると電 極と溶融金属間の電流方向が定まらないため飛散状況の 不安定性を招き，粒子径分布の広がりに繫ることが判明 したので，接触状態を改良する目的で(6)遅延時間設定装 置を考案し設定した。これは，溶融金属と電極との接触 によって電気的閉回路が形成されても直ちに通電させ ず,対向電極と溶融金属とのより完全な密着を図るため, 一定の時間経過を待って通電を開始させるものである. 遅延時間設定装置の機能を模式的に Fig. 3 に示す。ま ず，電流 $I$ が最初のピークで流れ溶融金属が飛散する
Table 1. Experimental conditions.

\begin{tabular}{ll}
\hline Current $I$ & $5 \sim 40 \mathrm{~A}$ \\
Voltage $\mathrm{V}_{\mathrm{e}}$ & $2 \sim 8.5 \mathrm{~V}$ \\
Magnetic field $B$ & $1.3 \mathrm{~T}$ \\
Nozzle diameter $d_{n}$ & $0.5 \mathrm{~mm}$ \\
Distance between nozzle and electrode $\quad$ & $0.5 \mathrm{~mm}$ \\
Temperature $T$ & $523 \sim 573 \mathrm{~K}$ \\
Delay time $t_{d}$ & $0 \sim 100 \mathrm{~ms}$ \\
Molten metal flow rate $q$ & $(0.07 \sim 1.42) \times 10^{-6} \mathrm{~m}^{3} / \mathrm{s}$ \\
\hline
\end{tabular}

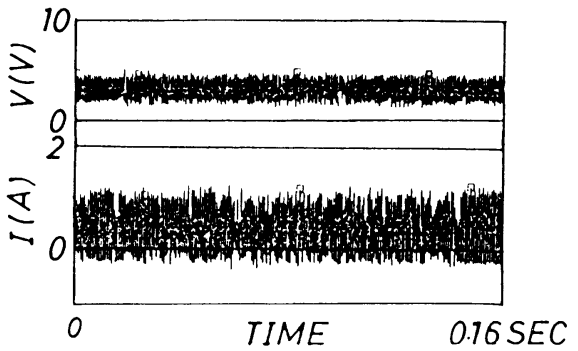

Fig. 4. Observed variations of voltage and current under the condition of zero delay time.

と，直ちに溶湯の供給が開始される。その間，電压が上 昇した状態を保つが，溶湯が電極に接触すると電压は降 下する。 その後, 設定した遅延時闒 $t_{d}$ の閒, 溶湯が供 給され続け電極と十分接触を果たした後， $t_{s}$ 時間通電さ れ飛散される。電流波形のピークからピークまでの時間 が飛散の時間間隔を示している.

通電により溶湯の温度上:昇が考えられるが，湯溜部や ノズル先端に設㯰した熱電対で読み取れるほどの温度変 化は見られなかった。

以上のようにして溶融金属の微粒化実験を行い，粒滴 化の様子を観察するとともに军真撮影を行った。また， ノズルから飛散された金属粒子の落下地点までの錦淔落 下距離と水头飛行距離を測定した。

なお，本実験条件を Table 1 に亦す。

\section{4. 実験結果および考察}

\section{$4 \cdot 1$ 遅延時間設定装置と飛散距離}

Fig. 4 は遅延時間設定装置を用いない場介の電流と電 圧の挙動を示す。これより電流と電历: の変化は激しく, 飛散が間断なく継続していることがわかる。記録計のブ ラウン管上で電流と電压の変化を拡大してみると飛散の 時間の間隔は約 $0.7 \mathrm{~ms}$ であった。

一方，Fig. 5 は遅延時間設定装䁇を用いて遅延時間を $20 \mathrm{~ms}$ に設定した場今の電流と電厅の変化を示したもの である。図より明らかに飛散は約 $27 \mathrm{~ms}$ の間隔で規則 的に行われていることがわかる。なお，刚中に見られる 口印は遅延時閒計測のために記録計のブラウン管上に入 


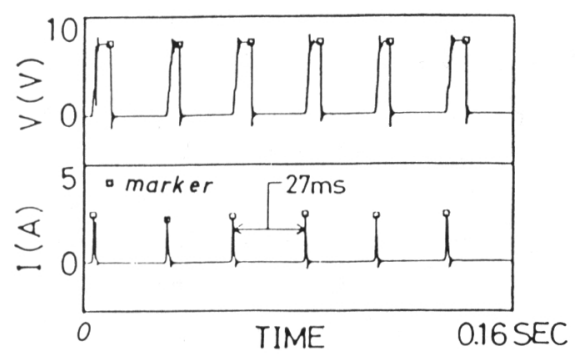

Fig. 5. Observed profiles of voltage and current under the condition of $20 \mathrm{~ms}$ delay time.
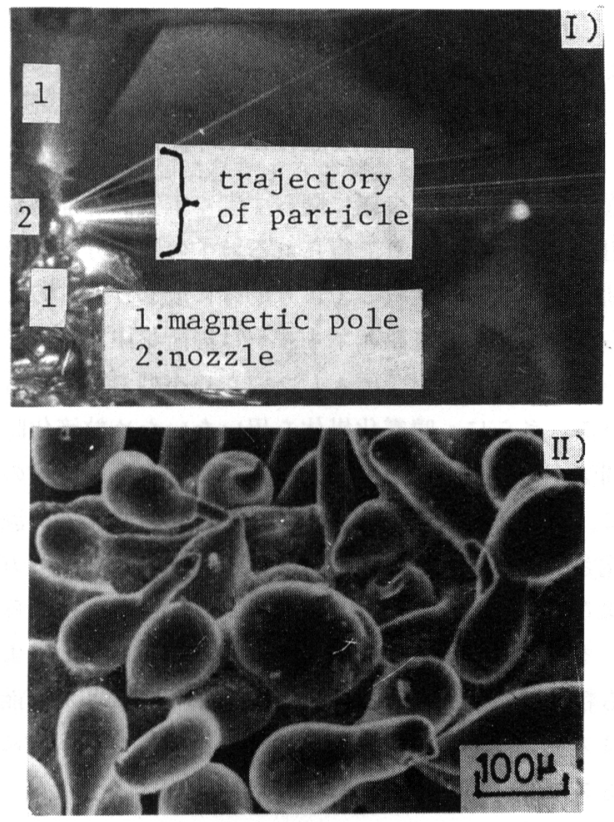

Photo. 1. I) Trajectory of particles in the electromagnetic atomization process under the condition of zero delay time (shutter speed : $1 / 30 \mathrm{~s}$ ) and II) SEM view of particles.

れたマーカーである. Photo. 1 は遅延時間を設定しな い場合の溶融金属の飛散状況を示したものであるＩ） の細く光沢を持って見える筋は飛散粒子の軌跡である.

II）はその時に得られた粒子の SEM 写真である. Fig. 6 に得られた粒子の粒径分布を示す。遅延時間設定装置 を用いない場合には, 溶融金属と電極との接触状態のば らつきから粒径分布が見られる.

Photo. 2 は遅延時間を $20 \mathrm{~ms}$ に設定した場合の飛散 状況を示したもので，I）の白く見える線分が飛散粒子 一個ずつの軌跡であり, 光跡がほぼ同じ長さであること から飛散が等時間間隔で行われていることがわかる。 な

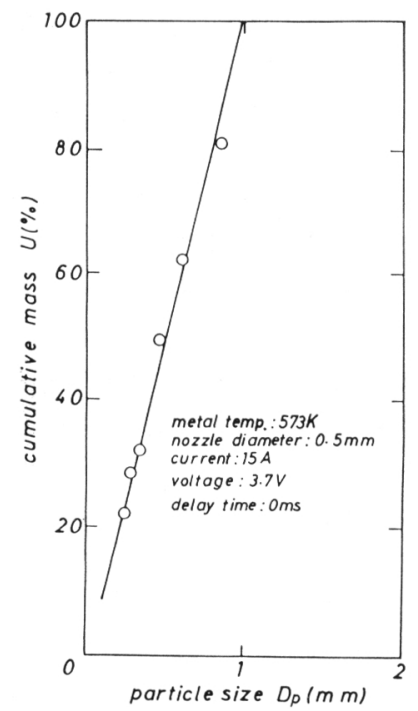

Fig. 6. Relationship between cumulative mass and particle size.
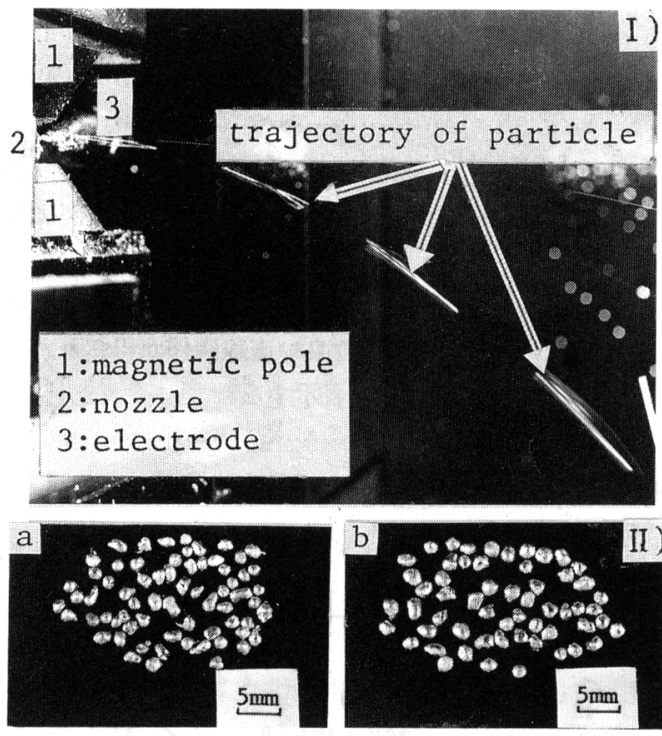

$\mathrm{q}=1.67 \times 10^{-7} \mathrm{~m}^{3} / \mathrm{s} \quad \mathrm{q}=3.43 \times 10^{-7} \mathrm{~m}^{3} / \mathrm{s}$

Photo. 2. I) Trajectory of particles in the electromagnetic atomization process under the condition of $20 \mathrm{~ms}$ delay time (shutter speed :1/30s) and II) micrograph of particles.

お，撮影に当たっては，飛散粒子からレンズを守るため レンズ前面に板ガラスを設置した。白く見える光跡が複 数個重なって見られるのはそのためである，II）に得ら 
れた粒子の写真を示した。右側（a ）は金属流出速度 $q$ $=1.67 \times 10^{-7} \mathrm{~m}^{3} / \mathrm{s}$, 左側 ( b ) は $q=3.43 \times 10^{-7}$ $\mathrm{m}^{3} / \mathrm{s}$ の場合である。遅延時間設定装置の導入により， 粒径はほぼ均一なものが得られた。すなわち，JIS 規格 の篩目の一間隔に相当する $D_{p}=1.45 \sim 1.19 \mathrm{~mm}$ (右側) $D_{p}=1.19 \sim 1.00 \mathrm{~mm}$ (左側) の範囲に入るものであった. また，流出速度の増大に伴って粒径は増大した。

\section{$4 \cdot 2$ 理論的考察}

溶融金属部分に誘発される単位体積当たりの電磁気力

に通電時間を掛けて求まる力積と飛散時の粒子の運動量 との関係を求める。

運動量と力積の関係は（1)式で表される。

$m v_{o}=V J B t_{s}$

(1)式を変形すると（2)式となる。

$\rho v_{o}=J B t_{s}$

（1），（2)式に表れる水平方向の飛散の初速度 $v_{0}$ は， 金属粒子の垂直方向落下距離 $h$ および水平飛行距離 $x$ を表す（3)，(4)式から $t$ を消去して得られる（5)式 を用いて， $h$ と $x$ の測定値から求める.

$$
\begin{aligned}
& h=(1 / 2) g t^{2} \\
& x=v_{o} t \cdots \cdots \cdots \\
& v_{0}=x \sqrt{g / 2 h}
\end{aligned}
$$

また, $J$ の值はFig. 5 に示した電流值 $I$ をノズル断面

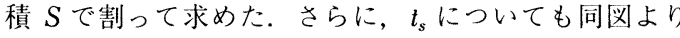
求めた。

測定值を（2)式の関係に基づいてプロットすると Fig. 7 に示すように，かなり良い直線関係が得られた。 この直線を（ 6 )式のように表示する。

$$
\alpha \rho v_{0}=J B t_{s}-\beta
$$

Fig. 7 に示した実測值を用いて最小自乗法により（6)

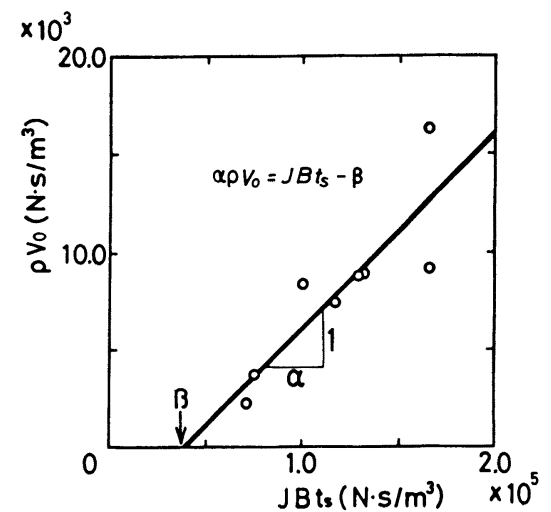

Fig. 7. Relationship between momentum and impulse.
式の $\alpha$ と $\beta$ の值を求めると $\alpha=0.1(-), \beta=0.38 \times$ $10^{5}\left[\mathrm{~N} \cdot \mathrm{s} / \mathrm{m}^{3}\right]$ が得られた。

$\alpha$ は一回の飛散で作られる金属档子小の数によって決ま る補正係数である，溶融金属が単・粒子として飛散され ている場合には， $\alpha=1$ となる. 本研究結果では $\alpha=$ 0.1 となったが，これは溶融金属と電極との接触状態の 不安定性に起因して，同時に数個の粒子が飛散され，そ の内の微粒子は空気中で燃焼消失するなどして，粒子の 回收が完全でないためと考えられるが，なお，この詳細 については現在，実験によって調查検邻中である。

一力， $\beta$ は溶融金属と電極間の付着力に基づく打積で あり，電磁気力が $\beta$ の值より大きくならないと飛散で きなかったことを示している。

\section{5. 電磁微粒化法の特徵}

電磁微粒化法は，金属に限らず店く電気伝導性物質に 適用できるものであり，得られる粒子の粒度分布と粒径 の制御も従来法に比較してより的確に成しうるものと考 えられる。また, 電磁エネルギーは局所集中が可能で, かつ機械的駆動部を必要としないため小型で簡素なもの となる，さらに，噴霧化媒体を用いないため粒滴化時の 雲囲気を自由に選択できるという特徵を有する。そのほ かに，印加する電流および磁場をそれぞれ直流，交流と 変化させ組み合わせることによって金属粒一の飛散方问 および粒滴化挙動を変化させることも叮能と考えられ る。また，磁場の方问を時間的に変化させることによっ ても粒子の飛散方向を連続的に変化させることが叮能て ありスプレーキャスティングの粒滴化装萓や，溶射にお けるスプレーガンとしての応用も期待できよう。

\section{6. 結言}

本研究の結果を以下に示す.

(1) 電磁気力を利用した浴融金属の微粒化法を考案 し，その試行実験を行った。そして靘磁気うに基づく溶 融金属の微粒化が叮能であることを確認した。

(2) 溶融金属と電極との接触状態が本プロセスの主要 因子であることを明らかにしここの接触状態を制御する ため遅延時間設定装置を考案した。

(3) 遅延時間設定装㯰により粒往分们の制御が叮能で あることを示した。

(4)電磁気力と通電時閏の積であるノ積と飛散粒子の 運動量との間に直線関係が存在することを埋㖮的に予測 し実験により確認した。

最後に，本研究経費の-・部は日本鉄銅協会特定基礎研 究会よりご援助いただいたことを䛉し謝意を表します。 
$B:$ 磁束密度 $[\mathrm{T}]$

記号

$D_{p}$ : 粒子往 $[\mathrm{mm}]$

$d:$ ノズルー電極間の溶融金属の直径 $[\mathrm{m}]$

$d_{n}:$ ノズルの直径 $[\mathrm{mm}]$

$g:$ 重力加速度 $\left[\mathrm{m} / \mathrm{s}^{2}\right]$

$h:$ 垂直力向落下距離 $[\mathrm{m}]$

$I$ : 印加電止: [ A ]

$J:$ 電流密度 $\left[\mathrm{A} / \mathrm{m}^{2}\right]$

$l:$ ノズル-電極間距離 $[\mathrm{mm}]$

$m:$ 粒子の質量 $[\mathrm{kg}]$

$q:$ 溶融金属の流量 $\left[\mathrm{m}^{3} / \mathrm{s}\right]$

$T:$ 溶融金属の温度 [K]

$t:$ 粒子一の滞空時間 [ $\mathrm{S}$ ]

$t_{d}:$ 遅延時間 $[\mathrm{ms}]$

$t_{s}:$ 通電時間 $[\mathrm{s}]$

$U:$ 累積頻度 $[\%]$

$V_{0}:$ 粒子の水济方间の初速度 $[\mathrm{m} / \mathrm{s}]$

$V:$ ノズルー電極閏に仔在する溶融金属の体積 $\left[\mathrm{m}^{3}\right]$
$V_{e}:$ 印加電圧 $[\mathrm{V}]$

$x:$ 飛散粒子の水平飛行距離 $[\mathrm{m}]$

$\alpha:(6)$ 式に表れる補正係数 $[-]$

$\beta$ : 溶融金属一電極間の付着力に起因する単位体積当たり

の力積 $\left[\mathrm{N} \cdot \mathrm{s} / \mathrm{m}^{3}\right]$

$\rho:$ 溶融金属の密度 $\left[\mathrm{kg} / \mathrm{m}^{3}\right]$

\section{文献}

1) S. Annavarapu, D. Apelian and A. Lawley: Proc. of 4 th Sympo., "Modeling of Casting and Welding Process", Palmcoast, FL, USA, (1988) Apr. 印刷中

2 ) 榛葉久吉, 三谷裕康: 標準金属学講座 6 “粉末治金学” (1962), p. 11 [コロナ社]

3 ) 河合伸泰, 佐藤義智, 関 義和: 資源処理技術, 33 (1986), p. 39

4 ）粉末治金技術協会, 粉末治金技術講座 3 (金属粉の生成) (1964), p. 52 [ 日刊工業新聞社]

5 ) A. LaWLEY: J. Met., 33 (1981) 1, p. 13

6 ) W. Fietsh: $\mathrm{P} / \mathrm{M}-82$ in Europe International Powder Metallurgy conference, Florence, Italy (1985) June, p. 739 